\title{
Length-weight relationship of Hoplias aff. malabaricus (Bloch, 1794) in a subtropical wetland
}

\author{
F. Corrêa ${ }^{a}$, S. Huckembeck ${ }^{b}$ and G. V. Canzianic \\ áaboratório de Ictiologia, Instituto de Oceanografia, Universidade Federal Rio Grande - FURG, \\ Campus Carreiros, CP 474, CEP 96201-900, Rio Grande, RS, Brazil \\ bLaboratório de Vertebrados, Instituto de Ciências Biológicas, Universidade Federal de Rio Grande - FURG, \\ Campus Carreiros, CP 474, CEP 96201-900, Rio Grande, RS, Brazil \\ 'Laboratório de Recursos Pesqueiros Demersais, Instituto de Oceanografia, Universidade Federal \\ de Rio Grande - FURG, Campus Carreiros, CP 474, CEP 96201-900, Rio Grande, RS, Brazil \\ *e-mail: correafecologia@yahoo.com.br
}

Received: March 26, 2015 - Accepted: July 21, 2015 - Distributed: November 30, 2016

Hoplias aff. malabaricus (Bloch, 1794) is a predatory fish from the Erythrinidae family, widely distributed, occurring in river basins of South America (Oyakawa and Mattox, 2009). This species has a vital role in ecosystems as top predator besides having an important economic value for fisheries (Chaves et al., 2009). Nevertheless, few studies are conducted on bioecological characteristics such as length - weight, which can provide information on morphometric variation in different populations, determining whether somatic growth is allometric or isometric (e.g. Froese, 2006). Moreover, these relationships are useful for fisheries in order to calculate weight and biomass when only length measurements are available as well as for making comparisons of stocks in different regions (Froese, 2006). Thus, the present study aims to determine the length-weight of specimens of $H$. aff. malabaricus collected in the Lagoa do Peixe National Park and to compare two methods of analysis (model linear and nonlinear).

The sampling of specimens was performed monthly in a wetland area $\left(31^{\circ} 06^{\prime} \mathrm{S}, 50^{\circ} 51^{\prime} \mathrm{W}\right)$, between April 2008 and May 2009 in the Lagoa do Peixe National Park (LPNP), with the special authorization provided by SISBIO $\left(\mathrm{N}^{\circ}\right.$ : 482920/2007-6). We measured the length and weight of 110 specimens for the determination of the length/weight. This ratio was determined by the equation $\mathrm{W}_{T}=a^{*} \mathrm{~L}_{T}{ }^{B}$, where $\mathrm{W}_{T}$ the total weight of fishes ( $\left.\mathrm{g}\right), a$ the coefficient related to body shape, $\mathrm{L}_{T}$ the total length ( $\mathrm{mm}$ ) and $b$ exponent that is related to the isometric or allometric growth of fishes. To adjust the model, we used PAST 3.0 statistical software to estimate the parameters $a$ and $b$ through a least square regression $\log \left(\mathrm{W}_{T}\right)=\log (\mathrm{A})+\mathrm{B} * \log \left(\mathrm{L}_{T}\right)$ and Statistica 7.0 to compute a direct non-linear regression, and to perform the Levenberg-Marquard iteration algorithm in order to compare the two methods.

Hoplias aff. malabaricus showed an average total length $\left(\mathrm{L}_{T}\right)$ of $177.3 \pm 79.3 \mathrm{~mm}$ and average total weight of $\left(\mathrm{W}_{T}\right) 127 \pm 162.83 \mathrm{~g}$. The parameters estimated by linear regression were: $a=-5,175[-5.291 ;-5.063], b=3.104$ $[3.053 ; 3.155]$, with $\mathrm{W}_{T}=0.0000668 * \mathrm{~L}_{T}^{3.104}$. The direct nonlinear regression showed the following results: $\mathrm{W}_{T}=0,0000344 * \mathrm{~L}_{T}^{3.23}$. In this study, $H$. aff. malabaricus has a positive allometric growth. We recommend using the nonlinear model whenever is possible, because is often more practical and robust than the linear model, which changes the relationship of the variables. The $b$ values (higher than three) indicate a nearly positive allometric growth pattern that is the fish have grown more in width or height than in length (Isa et al., 2010). Our findings are in agreement with Barbieri (1989), which found $b=3.18$ for this species on a study conducted with 404 specimens in a reservoir on a more tropical environment (Monjolinho Reservoir, São Carlos/SP). On the other hand, Chaves et al. (2009), studying the population structure of $H$. aff. malabaricus $(n=67)$ in northern Brazil, recorded a value of $b=2.25$. Differences among parameters values could be due to several factors, such as difference in the samples sizes, the range sizes of specimens, genetic differences among groups and local environmental conditions (Froese, 2006). The results obtained by Chaves et al. (2009) represent only a particular period of the year, which reflect a limited environmental condition and, thus, may affect the parameter values obtained in the length-weight relationship. The performance of growth observed shows a good conservation status of the species, important for the balance of community of fishes, as well as a better understanding of the relationships within the ecosystem and conservation.

\section{Acknowledgements}

We thank colleagues of the Ichthyology Laboratory of the Universidade Federal do Rio Grande - FURG for their assistance in the field; the Conselho Nacional de Desenvolvimento Científico e Tecnológico, CNPq (Grant No. 482920/2007-6) and International Foundation of Science, IFS (Grant No. A/4419-1) for providing financial support and the ICMBIO for providing permit (14523-2 and 14523-4) for sample collections. AMG acknowledges fellowship support from CNPq (305888/2012-9). 


\section{References}

BARBIERI, G., 1989. Dinâmica da reprodução e crescimento de Hoplias malabaricus (Bloch, 1974) (Osteichthyes, Erythinidae) da Represa do Monjolinho, São Carlos, SP. Revista Brasileira de Zoologia, vol. 6, no. 2, pp. 225-233. http://dx.doi.org/10.1590/ S0101-81751989000200006.

CHAVES, M.F., TORELLI, J., TARGINO, C.H. and CRISPIM, M.C., 2009. Dinâmica reprodutiva e estrutura populacional de Hoplias aff. malabaricus (Bloch, 1794) (Characiformes, Erythrinidae), em açude da Bacia do Rio Taperoá, Paraíba. Biotemas, vol. 22, no. 2, pp. 85-89.
FROESE, R., 2006. Cube law, condition factor and weight-length relationships: history, meta-analysis and recommendations. Journal of Applied Ichthyology, vol. 22, no. 4, pp. 241-253. http://dx.doi. org/10.1111/j.1439-0426.2006.00805.x.

ISA, M.M., RAWI, C.S.M., ROSLA, R., SHAH, S.A.M. and SHAH, A.S.R.M., 2010. Length-weight Relationships of freshwater fish species in Kerian river basin and Pedu lake. Research Journal of Fisheries and Hydrobiology, vol. 5, no. 1, pp. 1-8.

OYAKAWA, O.T. and MATTOX, G.M.T., 2009. Revision of the Neotropical trahiras of the Hoplias lacerdae species-group (Osta sriophysi:Characiformes:Erythrinidae) with descriptions of two new species. Neotropical Ichthyology, vol. 7, no. 2, pp. 117-140. http://dx.doi.org/10.1590/S1679-62252009000200001. 